\title{
Antitumor effect of free rhodium (II) citrate and rhodium (II) citrate-loaded maghemite nanoparticles on mice bearing breast cancer: a systemic toxicity assay
}

\author{
Raphael Cândido Apolinário Peixoto • Ana Luisa Miranda-Vilela • José de Souza Filho • \\ Marcella Lemos' Brettas Carneiro • Ricardo G. S. Oliveira • Matheus Oliveira da Silva • \\ Aparecido R. de Souza • Sônia Nair Báo
}

Received: 3 October 2014 / Accepted: 8 December 2014 / Published online: 21 December 2014

(C) The Author(s) 2014. This article is published with open access at Springerlink.com

\begin{abstract}
Breast cancer is one of the most prevalent cancer types among women. The use of magnetic fluids for specific delivery of drugs represents an attractive platform for chemotherapy. In our previous studies, it was demonstrated that maghemite nanoparticles coated with rhodium (II) citrate (Magh- $\mathrm{Rh}_{2} \mathrm{Cit}$ ) induced in vitro cytotoxicity and in vivo antitumor activity, followed by intratumoral administration in breast carcinoma cells. In this study, our aim was to follow intravenous treatment to evaluate the systemic antitumor activity and toxicity induced by these formulations in Balb/c mice bearing orthotopic 4T1 breast carcinoma. Female Balb/c mice were evaluated with regard to toxicity of intravenous treatments through analyses of hemogram, serum levels of alanine aminotransferase, iron, and creatinine and liver, kidney, and lung histology. The antitumor activity of rhodium (II) citrate $\left(\mathrm{Rh}_{2} \mathrm{Cit}\right)$, Magh- $\mathrm{Rh}_{2} \mathrm{Cit}$, and maghemite nanoparticles coated with citrate (Magh-Cit), used as control, was evaluated by tumor volume reduction, histology, and morphometric analysis. Magh- $\mathrm{Rh}_{2} \mathrm{Cit}$ and Magh-Cit promoted a significant
\end{abstract}

R. C. A. Peixoto • M. L. B. Carneiro · R. G. S. Oliveira •

S. N. Báo $(\square)$

Institute of Biological Sciences, Department of Cell Biology,

University of Brasília (UnB), Brasilia 70919-970, Brazil

e-mail:snbao@unb.br

A. L. Miranda-Vilela $\cdot$ J. d. S. Filho

Institute of Biological Sciences, Department of Genetics and

Morphology, University of Brasilia (UnB), Brasília, DF 70910-900,

Brazil

A. L. Miranda-Vilela

Faculty of Medicine, Faciplac, Campus Gama, Gama, DF, Brazil

M. O. da Silva • A. R. de Souza

Institute of Chemistry, Federal University of Goiás, Campus

Samambaia, Goiânia, Goiás 74001-970, Brazil decrease in tumor area, and no experimental groups presented hematotoxic effects or increased levels of serum ALT and creatinine. This observation was corroborated by the histopathological examination of the liver and kidney of mice. Furthermore, the presence of nanoparticles was verified in lung tissue with no morphological changes, supporting the idea that our nanoformulations did not induce toxicity effects. No studies about the systemic action of rhodium (II) citrateloaded maghemite nanoparticles have been carried out, making this report a suitable starting point for exploring the therapeutic potential of these compounds in treating breast cancer.

Keywords Rhodium (II) citrate · Maghemite nanoparticles · 4T1 breast cancer $\cdot$ Balb/c mice $\cdot$ Toxicological analysis

\begin{tabular}{|c|c|}
\hline \multicolumn{2}{|l|}{ Abbreviations } \\
\hline SPIOs & Superparamagnetic nanoparticles \\
\hline NPs & Nanoparticles \\
\hline RES & Reticuloendothelial system \\
\hline EPR & Enhanced permeability and retention \\
\hline $\mathrm{Rh}_{2} \mathrm{Cit}$ & Free rhodium (II) citrate \\
\hline Magh- $\mathrm{Rh}_{2}\left(\mathrm{H}_{2} \mathrm{cit}\right)_{4}$ or & Rhodium (II) citrate-loaded \\
\hline Magh-Rh ${ }_{2}$ Cit & maghemite nanoparticles \\
\hline Magh-Cit & $\begin{array}{l}\text { Maghemite nanoparticles coated with } \\
\text { citrate }\end{array}$ \\
\hline DMEM & Dulbecco's modified Eagle's medium \\
\hline FBS & Fetal bovine serum \\
\hline i.v. & Intravenous \\
\hline ALT & Alanine aminotransferase \\
\hline AVMA & $\begin{array}{l}\text { American Veterinary Medical } \\
\text { Association }\end{array}$ \\
\hline PBS & Phosphate-buffered saline \\
\hline $\mathrm{HE}$ & Hematoxylin-eosin \\
\hline
\end{tabular}




\begin{tabular}{|c|c|}
\hline HAI & Histopathological alteration index \\
\hline SEM & Standard error of mean \\
\hline $\mathrm{CNPq}$ & $\begin{array}{l}\text { Brazilian National Council for Tech- } \\
\text { nological and Scientific Development }\end{array}$ \\
\hline FAPDF & $\begin{array}{l}\text { Foundation to Support Research in } \\
\text { the Federal District }\end{array}$ \\
\hline CAPES & $\begin{array}{l}\text { Coordination for Further Training of } \\
\text { Graduate Staff }\end{array}$ \\
\hline UnB & University of Brasília \\
\hline
\end{tabular}

\section{Introduction}

Breast cancer is the most common type of cancer among women (excluding non-melanoma skin cancer) in both developed and developing countries [1]. Conventional treatments include surgery, radiotherapy, chemotherapy, and hormone therapy, and their effectiveness depends on the progress and type of the tumor [2, 3]. However, breast cancer remains one of the world's most devastating diseases, with more than 458,000 deaths and 1.38 million new cases each year [4, 5]. Chemotherapy, which is a common therapeutic approach, is used in high doses due to its lack of specificity to tumor cells, with consequent high systemic toxicity [6].

Therefore, the development of therapeutic strategies to selectively deliver drugs to the tumor, with no toxic effects on healthy tissues, represents an attractive area for breast cancer treatment. Among them, nanotechnology has been indicated as a new approach for cancer treatment over the past decade. It is starting to be used to develop imaging agents and nanosensors that detect biological signs of cancer and nanoparticles (NPs) that target cancerous cells with drugs [8]. The latter direction represents progress in relation to traditional therapies, since it would reduce systemic toxicity, thanks to the higher efficiency of drug delivery in chemotherapy. Indeed, superparamagnetic nanoparticles (SPIOs) mediating drug delivery, for instance, are used to target and accumulate drug molecules in the tumor, increasing the effectiveness of chemotherapy [7-9].

The small size of SPIOs has an influence on the passive transport of drugs through the tumor vessels and determines the speed at which they are removed by the reticuloendothelial system (RES). Firstly, SPIOs may have good physiological tolerance if they are functionalized with hydrophilic agents, preventing the opsonization by plasma protein [10-12]. Second, tumors larger than $2 \mathrm{~mm}^{3}$ have an increased demand for blood, resulting in the process of angiogenesis and leaky vasculature with $100-800-\mathrm{nm}$ pores, larger than those found in healthy blood vessels [8]. This defective architecture impairs lymphatic drainage near the tumor, increasing the enhanced permeability and retention (EPR) effect of SPIOs in the tumor $[13,14]$. Finally, SPIO-mediated drug delivery has the potential to enhance drug bioavailability, improve the time release of drug molecules, and enable precision drug targeting. It represents progress in relation to traditional therapies by reducing the systemic toxicity [7-9, 12, 15-17].

A variety of SPIOs coated with chemotherapy agents, including some inorganic compounds such as cisplatin and carboplatin, have been studied [18, 19]. Free rhodium (II) citrate $\left(\mathrm{Rh}_{2} \mathrm{Cit}\right)$ is also an inorganic and antitumor compound [20], which has been successfully stabilized by maghemite NPs [21]. Moreover, $\mathrm{Rh}_{2} \mathrm{Cit}$ presents hydrophilic groups, which improve its internalization by tumor cells and reduce the uptake by the RES [22].

Our research group has demonstrated that $\mathrm{Rh}_{2} \mathrm{Cit}$ and rhodium (II) citrate-loaded maghemite nanoparticles (Magh$\mathrm{Rh}_{2} \mathrm{Cit}$ ) induced significant cytotoxic effects on 4T1 and MCF-7 breast cancer cell lines. Moreover, these formulations reduced orthotopic 4T1 metastatic mammary carcinoma by intratumoral administration in Balb/c mice [23, 24]. Local injection therapy as intratumoral drug administration is commonly used for studying drug efficacy against non-metastatic tumors [25]. It results in less non-specific cytotoxic activity than with systemic treatments, which can induce adverse effects [26]. However, it is important to investigate the effect of the treatments by intravenous administration (i.v.), since this is one of the routes more frequently used in clinical treatment against breast metastatic cancer [6, 27]. Furthermore, no studies on the systemic action of $\mathrm{Rh}_{2} \mathrm{Cit}$ and Magh- $\mathrm{Rh}_{2} \mathrm{Cit}$ have been carried out, making this report a suitable starting point for exploring the therapeutic potential of these compounds in treating breast cancer.

Thus, we aimed to investigate the effect of systemic treatment with $\mathrm{Rh}_{2} \mathrm{Cit}$ and Magh- $\mathrm{Rh}_{2} \mathrm{Cit}$ on Balb/c mice bearing 4T1 mammary carcinoma. Maghemite nanoparticles coated with citrate (Magh-Cit) were used as control. The 4T1 cell line is suitable as an experimental animal model since it develops metastasis spontaneously from primary tumor, similar to human breast cancer, and also enables a rapid orthotopic tumor growth in Balb/c mice [28]. Moreover, the orthotopic model is appropriate for understanding the interaction of the drug with the tumor in its original microenvironment, being useful to recognize how cancer cells respond to the immune system, blood, hormones, and growth factors [29,30]. For this purpose, the use of NPs (Magh- $\mathrm{Rh}_{2}$ Cit and Magh-Cit) could improve drug delivery to the tumor to make the most effective cancer treatment $[8,9,11,22]$.

\section{Materials and methods}

Animals and procedures

A total number of $40 \mathrm{Balb} / \mathrm{c}$ female mice (12 weeks old) were purchased from the Multidisciplinary Center for Biological Investigation in Laboratory Animal Science (Cemib) of the 
State University of Campinas (Unicamp, SP/Brazil). All mice were maintained in plastic cages under standard conditions of 12-h dark/light cycle. The animals, weighing at the beginning of the experiment $21.83 \pm 1.52 \mathrm{~g}$, were fed with standard diet and water ad libitum.

Mice were evaluated with regard to the treatments' toxicity through analyses of blood, liver, kidney, and lung histology. In addition, the antitumor activity of rhodium (II) citrate and maghemite nanoparticles coated with rhodium (II) citrate was verified by tumor volume reduction, morphometry, and histology. All experiments described were approved by the Animal Research Ethics Committee of the University of Brasilia-Institute of Biologic Sciences, Brazil (UnBDOC no. 109434/2008).

Preparation of the rhodium (II) citrate and rhodium (II) citrate-loaded maghemite nanoparticles

All formulations $\left(\mathrm{Rh}_{2} \mathrm{Cit}\right.$, Magh- $\mathrm{Rh}_{2} \mathrm{Cit}$ and Magh-Cit) were prepared and characterized as previously described [23, 24]. Magh-Cit was used as control of NPs without rhodium. Briefly, $\mathrm{Rh}_{2}$ Cit was synthesized by exchanging trifluoroacetate ligands from the precursor rhodium (II) trifluoroacetate with citrate ligands. The compound was obtained as a green aqueous solution with a standardized concentration of $0.054 \mathrm{~mol} / \mathrm{L}$. Maghemite nanoparticles were synthesized by alkaline coprecipitation of $\mathrm{Fe}^{2+}$ and $\mathrm{Fe}^{3+}$ ions [31]. The particles obtained in the magnetite $\left(\mathrm{Fe}_{3} \mathrm{O}_{4}\right)$ phase were oxidized to maghemite $\left(\gamma-\mathrm{Fe}_{2} \mathrm{O}_{3}\right)$ by bubbling of oxygen gas and were subsequently purified by dialysis with deionized water for several days $([\mathrm{Fe}]=0.37 \mathrm{M})$. The Magh- $\mathrm{Rh}_{2}$ Cit was prepared using $5 \mathrm{~mL}$ of the colloidal dispersion with $1 \mathrm{~mL}$ of $\mathrm{Rh}_{2} \mathrm{Cit}$ and stirred for $24 \mathrm{~h}$.

Orthotopic tumor cell implantation and treatment

The 4T1 breast carcinoma cells were thawed and cultivated in flasks with Dulbecco's modified Eagle's medium (DMEM) (Sigma, St. Louis, MO) supplemented with $1 \%$ penicillin and $10 \%$ fetal bovine serum (FBS) at $37{ }^{\circ} \mathrm{C}$ in a humidified atmosphere with $5 \% \mathrm{CO}_{2}$. One week later, $\mathrm{Balb} / \mathrm{c}$ mice were anesthetized with ketamine $(80 \mathrm{mg} / \mathrm{kg})$ and xylazine $(10 \mathrm{mg} / \mathrm{kg})$ by intraperitoneal route. Then, $2 \times 10^{4} 4 \mathrm{~T} 1$ cells (in suspension in $50 \mu \mathrm{L}$ serum-free DMEM) were injected (1-mL-gauge needle) in their left mammary gland, which is the natural primary microenvironment of breast tumor occurrence.

Seven days after implantation of 4T1 cells, mice bearing tumor were distributed into four experimental groups $(n=8 /$ group), and each group was treated with $50 \mu \mathrm{L}$ of (1) $\mathrm{Rh}_{2} \mathrm{Cit}$, (2) Magh-Rh ${ }_{2}$ Cit, (3) Magh-Cit, or (4) water (solution solvent, control group). Treatments were carried out every 4 days by i.v. injection in the animal's tail vein, totalizing three applications of $0.5 \mathrm{mg} / \mathrm{kg}$ rhodium (II) citrate for each one (total dose of $\mathrm{Rh}_{2}$ Cit was $1.5 \mathrm{mg} / \mathrm{kg}$ ). Mice treated with Magh-Cit received the same iron concentration and nanoparticle amount found in Magh- $\mathrm{Rh}_{2} \mathrm{Cit}\left(14 \mathrm{mg} / \mathrm{kg}\right.$ and $2.4 \times 10^{15}$ particles). It were also included animals without tumor (healthy, $n=8$ ) for comparison with other groups exhibiting tumor.

During the experiments, deaths were registered for all mice bearing tumor, leaving at least five animals per group. Thus, three or five mice were used in each group for the following analysis. On the 19th day after tumor implantation, 4 days after the last treatment, mice were anesthetized as previously described, and blood samples $(1 \mathrm{~mL} /$ animal $)$ were collected by cardiac puncture to carry out hemogram and biochemical dosages of alanine aminotransferase (ALT), creatinine and serum iron. The animals were then immediately euthanized by cervical dislocation, according to the American Veterinary Medical Association (AVMA) guidelines for euthanasia [32]. Then tumor, liver, kidney, and lung were collected to perform antitumor and systemic toxicity analysis as described below.

\section{Tumor regression}

Tumors were surgically removed, their width and length were measured by a digital pachymeter (Stainless, Hardened), and the tumor volume was calculated according to the formula length $\times$ width $^{2} \times 0.52$ [33]. The tumor regression in experimental groups was evaluated by the tumor's volume, histopathology, and morphometry.

Tumors were fixed in $4 \%$ paraformaldehyde diluted in phosphate-buffered saline (PBS) for 4 hours at room temperature, transferred to $70 \%$ ethanol, included in paraffin using an automatic tissue processor (OMA ${ }^{\circledR}$ DM-40, São Paulo, Brazil), cut to $5 \mu \mathrm{m}$ of thickness in a Leica RM2235 manual microtome (Leica Microsystems, Nussloch, Germany) and stained with hematoxylin-eosin (HE) for histological analyses (light microscopy), in order to verify cell proliferation pattern, pleomorphism, degree of cell differentiation, and cell death. Morphometric analysis was also carried out to verify the percentage of coagulation necrosis for each treatment. Necrosis areas were measured as adapted from our previous reports $[8,37]$, with a total of three sections $(20 \mu \mathrm{m}$ far $)$ for each tumor collected from five mice per group.

Systemic toxicity analysis in mice bearing $4 \mathrm{~T} 1$ breast cancer after intravenous injection of compounds

In order to evaluate potential systemic toxicity induced by the treatments, clinical, histology and blood analyses were performed. Treated mice were continuously monitored for toxicity indexes such as weight loss, diarrhea, skin ulcers, and deaths; the time of animal death was recorded throughout the experimental period. 
Hemogram was processed in a multiple automated hematology analyzer (XZ 2100 Sysmex equipment), and serum biochemical analyses were run on the automated chemistry analyzer ADVIA 2400 (Siemens), using the appropriate Advia chemistry reagents, protocols, and controls.

Histopathology analysis of the liver, kidneys, and lungs was also performed in order to verify possible toxic effects induced by treatments. For this, tissues were fixed in Davidson's solution for $24 \mathrm{~h}$ at room temperature, transferred to $70 \%$ ethanol, and processed for histology as described above for tumors.

Possible histopathological alterations in the liver were verified and quantified though morphometry, using the histopathological alteration index (HAI) [34]. They were classified as progressive stages for the deterioration of organ functions: I (do not compromise the functioning of the organ), II (severe, affecting normal body functions), and III (very severe and irreversible). A value of HAI was calculated for each group of animals using the formula $\mathrm{HAI}=(1 \times \Sigma \mathrm{I})+(10 \times \Sigma \mathrm{II})+$ $(100 \times \Sigma$ III). Since I, II, and III correspond to the number of stages of change, the mean HAI was divided into five categories: $0-10=$ normal tissue; $11-20=$ mild to moderate damage to the tissue; $21-50=$ moderate to severe damage to the tissue; $51-100=$ severe damage to the tissue; and greater than $100=$ irreparable damage to the tissue. A morphometric model [35, 36] was also applied to obtain the volume, area, and diameter parameters of hepatocytes. Images of liver histopathological sections of three animals in each group were made with $\times 40$ objective lens, resulting in nine images per group. Measures of ten hepatocytes for each image were performed using Image Pro-Plus 6.0 software (Media Cybernetics, Silver Spring, USA/Microsoft ${ }^{\circledR}$ Windows 32-bit Systems Window ${ }^{\circledR}$ XP Vista). The volumetric measurements were estimated, considering the hepatocytes as a sphere with a volume $V=4 / 3 \pi R^{3}$ where the calculation of the radius $(R)$ was given by the formula $A=\pi R^{2}[37]$.

\section{Statistical analysis}

Statistical analysis was carried out using SPSS (Statistical Package for the Social Sciences) version 15.0. Data were expressed as mean \pm SEM (standard error of mean) and values of $p<0.05$ were considered statistically significant. The continuous variables were tested for normal distribution with the Shapiro-Wilk test. Differences among the analyzed groups were investigated through ANOVA when the data were normally distributed or through Kruskal-Wallis test in order to identify statistical difference when data were not normally distributed. For significant ANOVA and Kruskal-Wallis results, Bonferroni post-test and Mann-Whitney $U$ test were respectively used to carry out 2-by-2 comparisons between the treatments. For significant KruskalWallis results, Mann-Whitney $U$ test was performed to verify differences between the treatments (2-by-2 comparisons).
For the morphometric analysis of the liver, differences among groups were checked by ANOVA followed by the Tukey test, using the PDF Word Count \& Frequency Statistics Software 7.0. Values of $p<0.05$ were considered statistically significant.

\section{Results and discussion}

Tumor dimensions and morphometry

We verified that the tumor growth inhibition in the treatments with $\mathrm{Rh}_{2}$ Cit, Magh- $\mathrm{Rh}_{2}$ Cit, and Magh-Cit was about 45, 54, and $58 \%$, respectively (Fig. 1a). Although these rates were statistically non-significant compared to the control group, the treatments with Magh- $\mathrm{Rh}_{2}$ Cit and Magh-Cit also promoted a significant decrease in tumor area (Fig. 1b). Thus, Magh$\mathrm{Rh}_{2}$ Cit and Magh-Cit could be considered more efficient in retaining tumor aggressiveness and inducing its regression than $\mathrm{Rh}_{2}$ Cit. This may be related to the hydrophilicity of rhodium (II) citrate [20], which increases its dispersion by the body, especially when the treatments are performed intravenously.

In our previous study, under the same conditions of tumor establishment, mice that were intratumorally treated with $2.0 \mathrm{mg} / \mathrm{kg}$ (seven injections of $0.28 \mathrm{mg} / \mathrm{kg}$ each dose) of $\mathrm{Rh}_{2} \mathrm{Cit}$ free or associated to NPs (Magh- $\mathrm{Rh}_{2} \mathrm{Cit}$ ) presented a mean reduction in the tumor volume of 74 and $52 \%$, respectively [24]. Thus, in a local application, free rhodium (II) citrate has a higher antitumor effect than rhodium (II) citrate associated with NPs. This corroborates the suggestion that the systemic application of $\mathrm{Rh}_{2}$ Cit resulted in an increase of its dispersion by the body, probably because of its hydrophilicity [20], and this could have caused a minor tumor reduction when compared to Magh$\mathrm{Rh}_{2}$ Cit or Magh-Cit.

Additionally, it is possible that the combination of NPs with $\mathrm{Rh}_{2}$ Cit may have improved the passive targeting of nanoparticles $\left(\mathrm{Magh}-\mathrm{Rh}_{2} \mathrm{Cit}\right)$ to the tumor due to the EPR effect in abnormal tissue, which is characterized by a leaky vasculature in combination with poor lymphatic drainage around the tumor [38]. Tumor microvasculature typically contains pores ranging from 100 to $1000 \mathrm{~nm}$ in diameter, while in most healthy tissue, there are tight intercellular junctions of less than $10 \mathrm{~nm}$ [17]. Therefore, the EPR effect may have caused the accumulation of NPs next to tumor tissues since the hydrodynamic size of the NPs used in the experiments was $60 \mathrm{~nm}$ [21]. This size is greater than the intercellular gap of the healthy tissue, while it is smaller than the pores found within the tumor vasculature. Thus, nanoscale architecture may have selectively targeted Magh- $\mathrm{Rh}_{2} \mathrm{Cit}$ and Magh-Cit to the tumor, resulting in higher inhibition of tumor growth compared to $\mathrm{Rh}_{2} \mathrm{Cit}$ [17]. Furthermore, neoplastic cells require higher amounts of micronutrients, such as iron, for 
Fig. 1 Dimensions,

morphometry, and histology of $4 \mathrm{~T} 1$ tumor tissue sections of the non-treated and treated groups. a Tumor volume. b Tumor area (morphometry). c Percentage of necrosis area (morphometry). d Description of coagulation necrosis. e-h Histopathological aspects by $\mathrm{H} \& \mathrm{E}$ staining,

showing a central area of necrotic tissue surrounded by viable tumor cells in the peripheral areas of tumors without treatment (control group, e) and those of the treatment groups $\mathrm{Rh}_{2} \mathrm{Cit}(\mathbf{f})$, Magh- $\mathrm{Rh}_{2}$ Cit (g), and Magh-Cit (h). Pyknotic nuclei (white arrow). Karyolysis (black arrow). Karyorrhexis (arrow head). Bars $=0.5 \mathrm{~mm}$
A

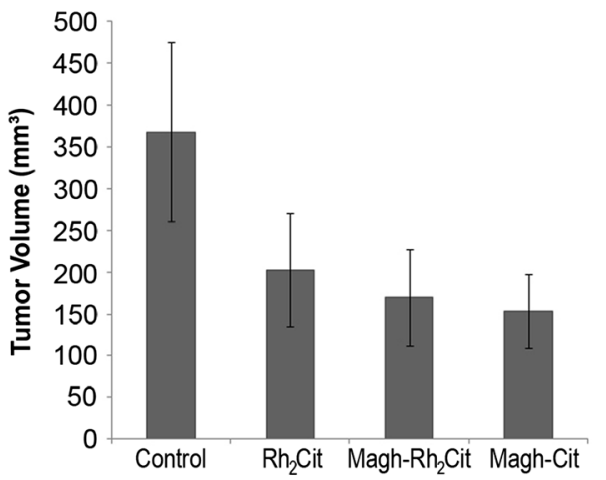

\section{C}
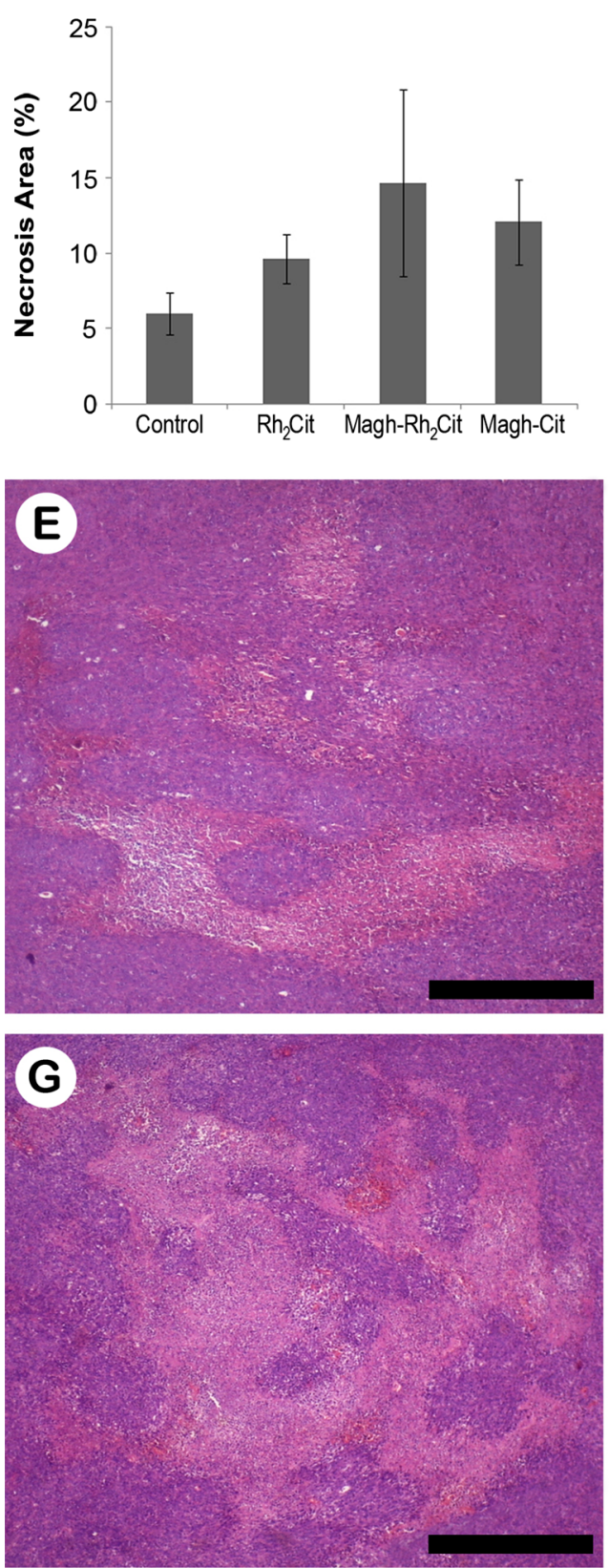
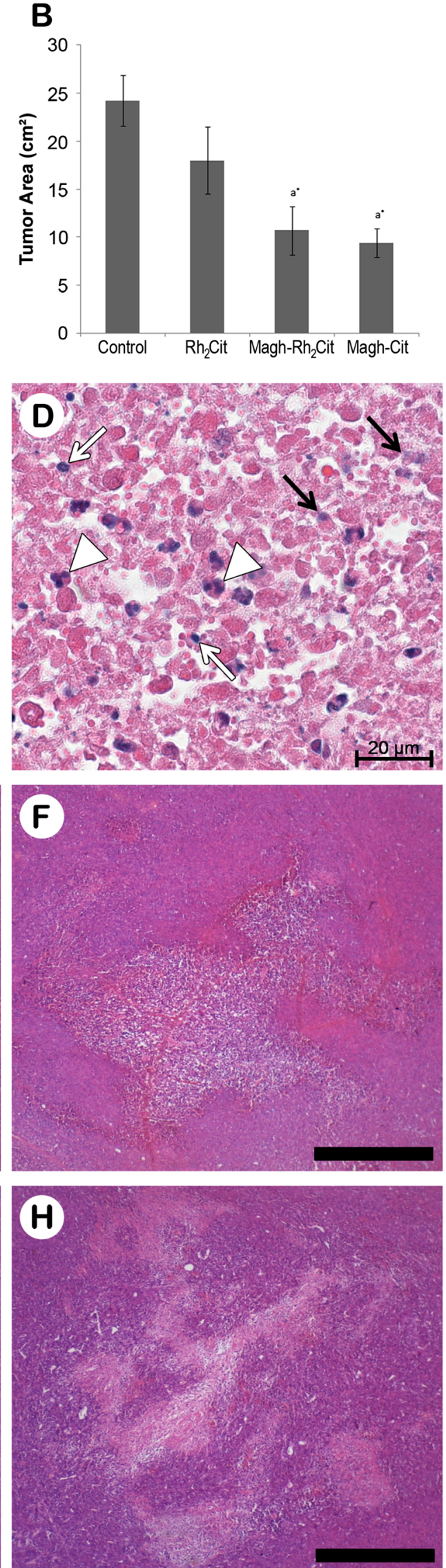
cell division, possibly leading maghemite NPs to target the tumor [39]. This could explain the significant differences observed in serum iron of Magh- $\mathrm{Rh}_{2} \mathrm{Cit}$ and Magh-Cit groups in relation to healthy animals and control and $\mathrm{Rh}_{2} \mathrm{Cit}$ (Table 1).

The antineoplastic effect was also showed by the morphometry of the tumors' necrotic areas, with an increase in its percentage mean in all treatments (Fig. 1c). Even though data presented non-significant values compared to the control, these analyses corroborated tumor volume measurements, except that Magh- $\mathrm{Rh}_{2}$ Cit promoted a higher percentage of tumor necrosis than Magh-Cit (Fig. 1a, c). This result was possibly due to the presence of rhodium, which induced a better antitumor effect. However, the fact that $\mathrm{Rh}_{2}$ Cit treatments caused a smaller necrosis area than Magh-Cit might be related to the greater dispersion of free rhodium through the body, as described above (Fig. 1e-h).

Furthermore, the antitumor effect of Magh-Cit may be related to the fact that citric acid is a good antioxidant [40] and the most effective inhibitor of glycolysis, making it useful to fight cancer. For this purpose, citrate can be applied as an inhibitor of the phosphofructokinase enzyme, the pyruvate dehydrogenase complex, and the succinate dehydrogenase enzyme of the Krebs cycle, blocking glycolysis and, thus, resulting in limited metabolism of the mitochondria and low reproduction capacity of the cell in general [41]. Accordingly, citric acid has been described as an antineoplastic treatment in patients with terminal medullary thyroid cancer [42] and terminal peritoneal mesothelioma [43]. In this context, the use of Magh- $\mathrm{Rh}_{2}$ Cit resulted in the highest mean percentage of the necrosis area and may have caused a greater antitumor effect in mice due to three activities: the local rhodium effect, the NP-mediated drug delivery to the tumor, and the inhibition of glycolysis by citrate.

Histopathological analyses of the mammary gland and tumors

Histological analysis of the mammary gland of healthy mice showed peculiar parenchyma and stroma with ducts surrounded by connective and adipose tissue, and the presence of a lymph node (Fig. 2a). In the 4T1-bearing mice, the neoplastic tissues in all groups presented malignant anaplastic tumors with cells not specialized and distinct from the original parenchyma (Fig. 2b-i). The fast growth of cancer cells upon the parenchyma and stroma of breast tissue is related to

Table 1 Effects of $\mathrm{Rh}_{2}$ Cit, Magh- $\mathrm{Rh}_{2}$ Cit, and Magh-Cit on hematology and biochemical parameters of female Balb/c mice 19 days after animals' tumor transplantation

\begin{tabular}{|c|c|c|c|c|c|c|}
\hline Treatments & Healthy & Control & $\mathrm{Rh}_{2} \mathrm{Cit}$ & Magh- $\mathrm{Rh}_{2} \mathrm{Cit}$ & Magh-Cit & $\begin{array}{l}p \text { - } \\
\text { values }\end{array}$ \\
\hline \multicolumn{7}{|l|}{ Hematology } \\
\hline $\operatorname{RBCs}\left(\times 10^{6} / \mathrm{mm}^{3}\right)$ & $9.61 \pm 0.05$ & $9.06 \pm 0.15 * a$ & $7.55 \pm 1.34 * \mathrm{a}$ & $9.43 \pm 0.16$ & $9.47 \pm 0.12$ & 0.046 \\
\hline $\mathrm{HGB}(\mathrm{g} / \mathrm{dL})$ & $14.88 \pm 0.54$ & $14.62 \pm 0.10$ & $12.16 \pm 2.31$ & $15.12 \pm 0.29$ & $14.46 \pm 0.19$ & 0.300 \\
\hline HCT $(\%)$ & $45.30 \pm 0.37$ & $43.58 \pm 0.55$ & $35.16 \pm 6.23 * a$ & $44.44 \pm 0.73$ & $44.00 \pm 0.50$ & 0.084 \\
\hline MCV (fL) & $47.15 \pm 0.44$ & $48.17 \pm 0.86$ & $46.70 \pm 0.34$ & $47.12 \pm 0.25$ & $46.50 \pm 0.55$ & 0.281 \\
\hline MCH (pg) & $15.48 \pm 0.49$ & $16.13 \pm 0.25$ & $15.72 \pm 0.70$ & $16.04 \pm 0.09$ & $15.28 \pm 0.14 * b, d$ & 0.094 \\
\hline $\mathrm{MCHC}(\mathrm{g} / \mathrm{mL})$ & $32.88 \pm 1.33$ & $33.57 \pm 0.27$ & $33.68 \pm 1.73$ & $34.04 \pm 0.18$ & $32.88 \pm 0.27$ & 0.878 \\
\hline Platelets $\left(\times 10^{3} / \mathrm{mm}^{3}\right)$ & $503.25 \pm 53.63$ & $484.50 \pm 23.75$ & $393.80 \pm 86.04$ & $428.20 \pm 74.85$ & $509.20 \pm 43.54$ & 0.592 \\
\hline $\mathrm{WBC}\left(/ \mathrm{mm}^{3}\right)$ & $5193 \pm 1688$ & $15,738 \pm 4593$ & $18,462 \pm 13,158$ & $13,576 \pm 2685$ & $14,768 \pm 3929$ & 0.249 \\
\hline Lymphocytes (\%) & $84.25 \pm 1.93$ & $8.17 \pm 5.27 * \mathrm{a}$ & $6.00 \pm 3.27 * \mathrm{a}$ & $13.60 \pm 10.09 * \mathrm{a}$ & $4.40 \pm 2.68 * \mathrm{a}$ & 0.035 \\
\hline Neutrophils (\%) & $12.25 \pm 1.65$ & $85.33 \pm 4.65 * a$ & $90.40 \pm 3.31 * a$ & $80.40 \pm 9.53 * a$ & $92.40 \pm 2.38 * \mathrm{a}$ & 0.014 \\
\hline Eosinophils (\%) & $0.75 \pm 0.25$ & $0.33 \pm 0.21$ & $0.60 \pm 0.25$ & $0.60 \pm 0.25$ & $0.20 \pm 0.20$ & 0.451 \\
\hline Monocytes (\%) & $2.75 \pm 1.18$ & $6.00 \pm 1.81$ & $2.40 \pm 0.68$ & $5.20 \pm 1.24$ & $2.80 \pm 0.37$ & 0.203 \\
\hline \multicolumn{7}{|l|}{ Biochemical } \\
\hline ALT (U/L) & $32.40 \pm 3.04$ & $24.29 \pm 2.88$ & $30.20 \pm 3.25$ & $23.00 \pm 0.89$ & $31.00 \pm 2.71$ & 0.087 \\
\hline Creatinine (mg/dL) & $0.40 \pm 0.00$ & $0.21 \pm 0.01 * \mathrm{a}$ & $0.22 \pm 0.02 * \mathrm{a}$ & $0.20 \pm 0.00 * \mathrm{a}$ & $0.22 \pm 0.02 * \mathrm{a}$ & 0.001 \\
\hline Serum Fe $(\mu \mathrm{g} / \mathrm{dL})$ & $180.80 \pm 7.37$ & $130.00 \pm 7.21 * \mathrm{a}$ & $133.80 \pm 13.43 * \mathrm{a}$ & $148.40 \pm 12.09$ & $161.33 \pm 4.59$ & 0.004 \\
\hline
\end{tabular}

Legend: $R B C$ red blood cells, $H G B$ hemoglobin, $H C T$ hematocrit, $M C V$ mean corpuscular volume, $M C H$ mean corpuscular hemoglobin, $M C H C$ mean corpuscular hemoglobin concentration, WBC white blood cells, $A L T$ alanine transaminase

*Values are represented as mean \pm standard error $(p<0.05)$

${ }^{\text {a }}$ Significant compared to the healthy group

${ }^{\mathrm{b}}$ Significant compared to the control group

${ }^{\mathrm{c}}$ Significant compared to the group treated with Magh-Rh2Cit 
morphological changes, such as loss of polarity due to pleomorphic cells and a large amount of typical and atypical mitosis, with three spindle poles, as shown in Fig. 2g. These features are related to the high malignancy of $4 \mathrm{~T} 1$ cells, which were described as an invasive lineage, representing a suitable model to evaluate the efficacy of anticancer drugs due to its similarities with metastatic human breast cancer [29].

Tumors were more invasive in the control group (water administration). This was evidenced by the presence of more local invasion in the muscle fibers beneath the tumors (Fig. 2b). A dense inflammatory reaction was seen around tumors in the $\mathrm{Rh}_{2}$ Cit group compared to other groups, corroborating the findings of our previous study [24]. Moreover, various tumor cells were observed in a process of necrosis with hemorrhagic areas in tissues of $\mathrm{Rh}_{2} \mathrm{Cit}$, Magh-Rh ${ }_{2}$ Cit, and Magh-Cit groups (Fig. 2e, $\mathrm{f}$, i). Necrotic tissues showed disorganized cellular debris with indistinct boundaries, pyknotic nuclei, and eosinophilic cytoplasm, forming a homogeneous amorphous tissue (Fig. 1d).

Systemic toxicity assessment in mice bearing $4 \mathrm{~T} 1$ breast carcinoma

During the whole experimental period (19 days), the in vivo survival rates of all animals were examined. Deaths started on experimental day 13 after tumor implantation and occurred until euthanasia, totalizing nine deaths in all groups with tumor. The final survival rates of mice were of $100 \%$ in the healthy group, $87.5 \%$ (one death) in the tumor control group, $62.5 \%$ (three deaths) in the $\mathrm{Rh}_{2} \mathrm{Cit}$ and Magh- $\mathrm{Rh}_{2}$ Cit groups, and $75 \%$ (two deaths) in the Magh-Cit group (Fig. 3). However, no evident alterations in clinical parameters were found during the whole experimental period, which indicated the good tolerance of mice to treatments. Thus, the survival rates in mice treated with these formulations should be attributed to the natural invasiveness of the tumor and not to the treatments themselves.

Values of erythrogram of mice in the control group and those treated with $\mathrm{Rh}_{2} \mathrm{Cit}$, Magh- $\mathrm{Rh}_{2} \mathrm{Cit}$, and Magh-Cit remained similar to those of healthy mice. Still, a significant reduction in $\mathrm{RBC}$ was observed in the control and $\mathrm{Rh}_{2} \mathrm{Cit}$ groups and in HCT in the $\mathrm{Rh}_{2}$ Cit group (Table 1). However, although concurrent controls are used as the primary comparison for interpretation of treatment-related changes, comparison to reference intervals may also be useful to put hematological changes in perspective [44]. In this context, we concluded that there were no hematotoxic effects for all experimental groups, since RBC, HCT, and the other variables of the hemogram remained inside the reference range described for female mice $\left(6.5-10.1 \times 10^{6} / \mu \mathrm{L}\right.$ for $\mathrm{RBC}$ and $32.8-48 \%$ for
Fig. 2 Representative histopathology of mammary gland and tumors developed from $\mathrm{Balb} / \mathrm{c}$ mice bearing $4 \mathrm{~T} 1$ breast carcinoma in non-treated and treated groups. Tumor slides were stained with H\&E. a Healthy group. b, c Control. d, e $\mathrm{Rh}_{2}$ Cit. f, g Magh- $\mathrm{Rh}_{2}$ Cit. h, i Magh-Cit. Adipocyte $(a)$. Duct $(d)$. Hemorrhage $(h)$. Lymph node $(L)$. Muscle fibers $(m)$. Necrosis areas $(n)$. Tumor $(t)$. Blood vessel $(v)$. Mitosis (arrow heads). Infiltration of inflammatory cells (arrow). Three spindle poles (large arrow)
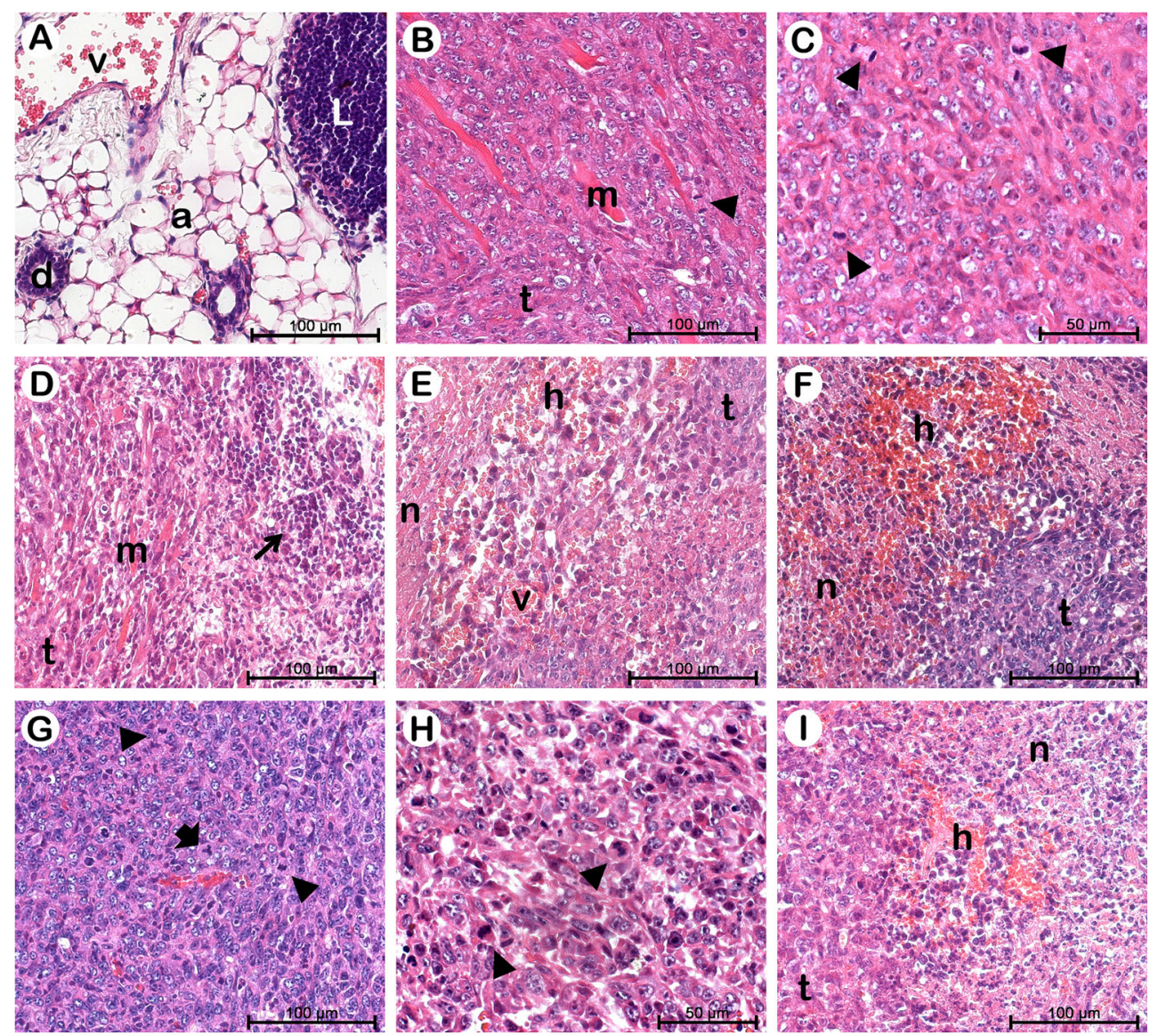


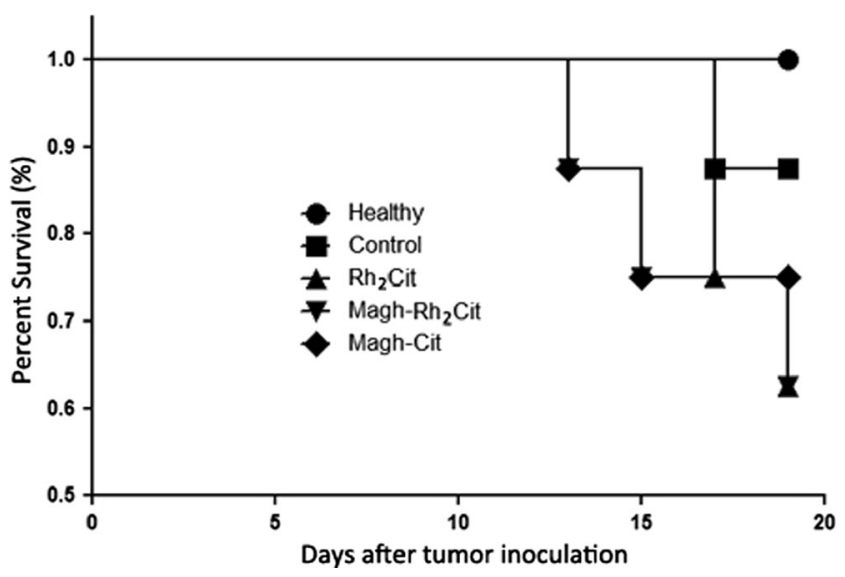

Fig. 3 Survival curve for tumor-bearing mice during 19 days of nontreated and treated groups. Animals received intravenous administration in tail vein of three doses of $0.5 \mathrm{mg} / \mathrm{kg}(1.5 \mathrm{mg} / \mathrm{kg}$ total dose) rhodium (II) citrate for $\mathrm{Rh}_{2} \mathrm{Cit}$ and Magh- $\mathrm{Rh}_{2}$ Cit treatments, and the same iron concentration and nanoparticle amount for Magh- $\mathrm{Rh}_{2} \mathrm{Cit}$ and Magh-Cit. Values represent mean values \pm standard error ( $n=8 /$ each group). Animals without tumor and without treatment (healthy) were also included in this study as negative control group

HCT) [45]. The hematological changes could be related to the development of the tumor, according to these reference values. This observation is supported by the leukogram data, whereas there were no significant differences regarding the WBC, compared to healthy animals.

Generally, in all groups, we observed a significant decrease in the percentage of lymphocytes with a concomitant increase in the percentage of neutrophils after tumor implantation (Table 1), corroborating the results of other studies in our group $[8,37,49]$. The relative WBC counts have been reported as a non-relevant parameter, as it is the absolute counts that must be reported and interpreted [46]. Overall, the results support the finding that there were no hematotoxic effects in all treatment groups.

Our histopathological analyses of the lung corroborated the relative WBC counts, showing alveolar wall vessels with an increase in the number of neutrophils in animals bearing mammary carcinoma (Fig. 4f, i, 1, o), while the healthy group presented a low concentration of leucocytes (Fig. 4c). However, the rise in WBC was restricted to vessels, with no evident perivascular infiltration of inflammatory cells, even in animals treated with Magh- $\mathrm{Rh}_{2}$ Cit and Magh-Cit, which presented NPs inside blood vessels and in perivascular parenchyma (Fig. 4l, o). Moreover, no foamy cells, pulmonary fibrosis, or presence of granulomatous lesions were observed in lung tissues of all treatment groups (Fig. 4). Thus, we concluded that our nanoformulations were non-toxic, since there was no morphological change in the lung tissue in all experimental groups.

Along with the hemogram, evaluation of the serum biochemical parameters is crucial for identifying the possible occurrence of toxicity induced by a new drug, and it must be correlated with histopathology tests [46]. Thus, serum levels
Fig. 4 Representative histopathology of liver, kidney, and lung from healthy Balb/c mice and Balb/c mice bearing 4T1 breast carcinoma in non-treated and treated groups. The animals were treated with the same $\mathrm{Rh}_{2}$ Cit concentration ( $1.5 \mathrm{mg} / \mathrm{kg}$ total dose), and they were euthanized on the 19th day after tumor inoculation. In general, no morphological alterations were found in the kidneys and lungs of mice. Increased neutrophilis were found in all mice bearing mammary carcinoma, and we also observed nanoparticles in lung tissue of mice treated with Magh$\mathrm{Rh}_{2}$ Cit and Magh-Cit. Organ sections were stained with H\&E. Healthy mice (a-c) and mice bearing 4T1 breast carcinoma without treatment (df) or treated with $\mathrm{Rh}_{2} \mathrm{Cit}(\mathbf{g}-\mathbf{i})$, Magh- $\mathrm{Rh}_{2} \mathrm{Cit}(\mathbf{j}-\mathbf{l})$, and Magh-Cit (m-o). Fibrosis (circle). Hepatocyte degeneration (square). Inflammation (rectangle). Nanoparticles (white arrow). Nucleus degeneration (pentagon). Pyknotic nuclei (arrow). Vacuolization (arrow head). Nucleus hypertrophy (white arrow head)

of ALT were measured to assess possible dysfunctions in the hepatobiliary system $[46,47]$ arising from the tumor implantation and/or treatments. Serum creatinine was used as a kidney function test [46], and the results were compared to the histopathological analyses of these organs (Fig. 4). ALT is a cytoplasmic enzyme in which the serum activity is increased due to leakage across damaged cytoplasmic membranes. In mice, ALT is found in the highest concentration in the liver, although its activity has also been demonstrated in the intestine, kidney, heart, muscle, and brain. Despite its widespread tissue distribution, ALT is widely considered to be a serum biomarker of hepatocellular injury [46], being used as an indicator of drug-induced liver hepatotoxicity [48]. In this study, ALT levels showed no significant statistical differences (Table 1), as all groups were within the reference values reported for female Balb/c mice [46].

On the other hand, compared to healthy animals' liver, we verified a significantly increased HAI in the control group and a higher value in the treatment groups (Fig. 4a, d, g, j, m). It was observed that the untreated animals (control group) had HAI above 100, indicating that the liver function was irreparably affected by signs of fibrosis. These changes in the liver, classified as stage III, prevent the restoration of its functional structure (Fig. 5b) [34]. For the animals treated with $\mathrm{Rh}_{2} \mathrm{Cit}$, Magh- $\mathrm{Rh}_{2} \mathrm{Cit}$, and Magh-Cit, the mean of liver tissue changes was between 21 and 50, indicating the presence of liver abnormalities ranging from moderately to heavily damaged [49] (Fig. 5a).

In the measurements of the hepatocytes, the control group had significantly increased nucleus area and volume compared to the healthy group, causing liver hypertrophy, but this was improved by the treatments. Animals treated with $\mathrm{Rh}_{2} \mathrm{Cit}$ and Magh-Cit showed a significant reduction in the hepatocyte diameter (Table 2). These results could be associated with the presence of inflammatory infiltrate observed near blood vessels, mainly close to the NP agglomerations (Fig. $4 \mathrm{j}, \mathrm{m}$ ). These inflammatory infiltrates, known as inflammatory pseudotumors (IPTs), are the expression of diverse 

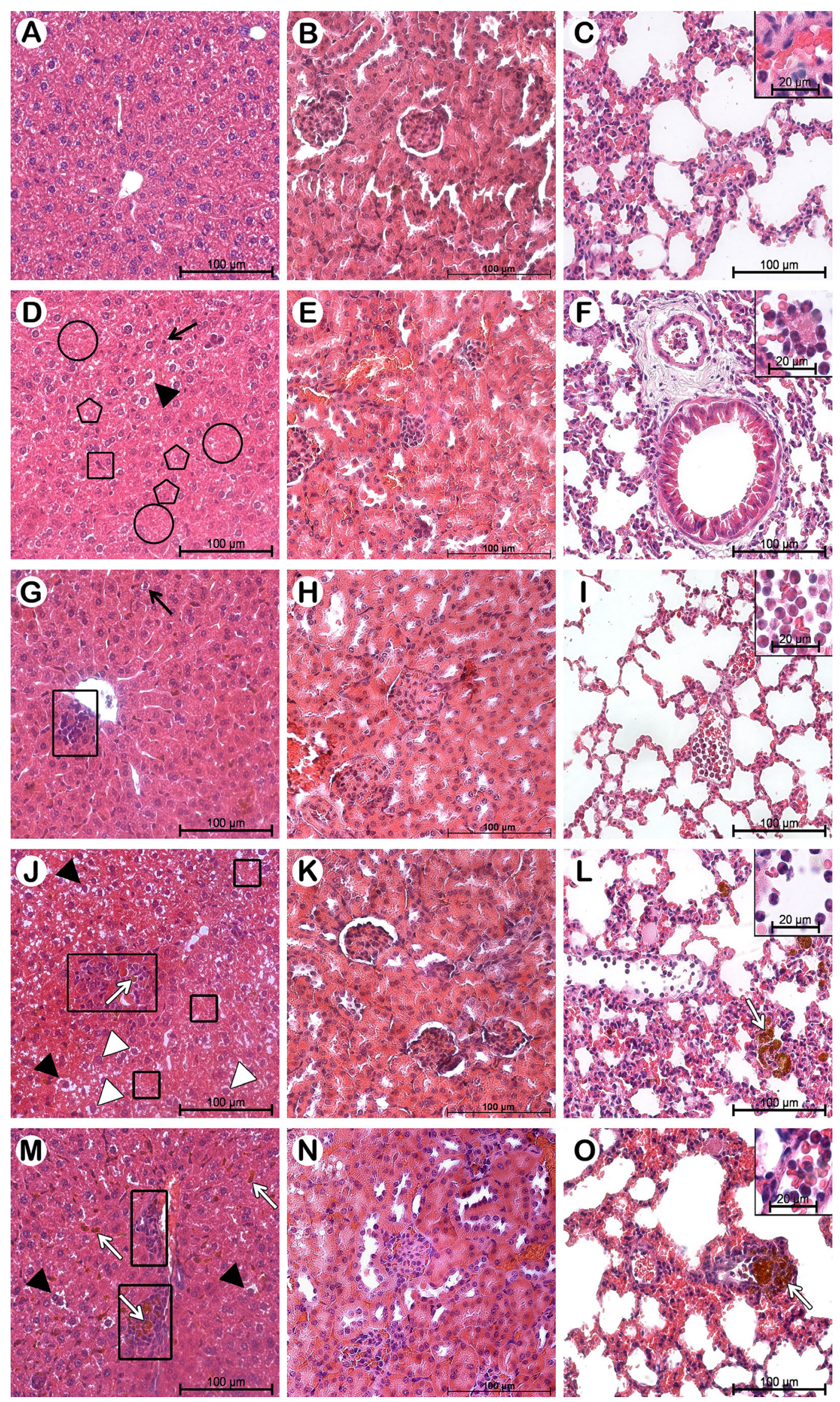
A

\begin{tabular}{lcccccc}
\hline \multicolumn{1}{c}{ Alterations } & Stage & Healthy & Control & $\mathrm{Rh}_{2}$ Cit & Magh-R $\mathrm{h}_{2} \mathrm{Cit}$ & Magh-Cit \\
\hline Cellular hypertrophy & I & ++ & +++ & +++ & ++ & +++ \\
Nuclear hypertrophy & I & ++ & +++ & +++ & ++ & +++ \\
Irregular cells & I & + & +++ & ++ & ++ & ++ \\
Irregular nuclei & I & + & +++ & ++ & ++ & +++ \\
Peripheral nuclei & I & $\mathbf{0}$ & +++ & + & ++ & ++ \\
Cytoplasm vesicles & I & + & +++ & + & +++ & +++ \\
Hepatocyte degeneration & II & $\mathbf{0}$ & +++ & + & ++ & ++ \\
Nuclei degeneration & II & + & ++++ & 0 & ++ & +++ \\
Pyknotic nuclei & II & + & +++ & +++ & ++ & ++ \\
Hemorrhage & II & $\mathbf{0}$ & + & $\mathbf{0}$ & $\mathbf{0}$ & $\mathbf{0}$ \\
Inflammation & II & $\mathbf{0}$ & $\mathbf{0}$ & +++ & ++ & +++ \\
Fibrosis & III & $\mathbf{0}$ & +++ & $\mathbf{0}$ & $\mathbf{0}$ & $\mathbf{0}$ \\
\hline Note: $0=$ absent; + = fairly frequent; ++ = frequent; +++ = very frequent; ++++ extremely frequent.
\end{tabular}

Fig. 5 Histopathological alterations found in the liver of Balb/c mice bearing $4 \mathrm{~T} 1$ breast carcinoma in non-treated and treated groups. The animals were treated with the same $\mathrm{Rh}_{2}$ Cit concentration $(1.5 \mathrm{mg} / \mathrm{kg}$ total dose), and they were euthanized on the 19th day after tumor inoculation. Liver sections were stained with H\&E. a Alterations were classified as progressive stages (I, II, and III) for the deterioration of liver

inflammatory processes that may be accompanied by a tumorlike mass [50]. The IPTs in the hepatic tissue may suggest that NPs activate the phagocytic activity to help in removing the accumulated NPs. Thus, this process could represent a defense mechanism of detoxification which may be correlated with the amount of injury to the hepatic tissue [51]. In the untreated animals (control group), the tumor growth induced irreversible pathological changes, with no reestablishment of the functional structure of the liver due to the presence of signs of fibrosis (Fig. 4d). The histopathological changes in the liver may therefore have been caused by breast tumor growth, leading to physiological disorders.

Creatinine is a degradation product of creatine and creatine phosphate and represents an end product of muscle metabolism. Pathologically, elevated serum creatinine levels can be caused by prerenal, renal, and postrenal conditions. Prerenal causes include increased protein catabolism, such as that which occurs in inflammation or with high-protein diets. Renal causes are usually associated with conditions that compromise $70-75 \%$ of functional renal mass, and postrenal

\section{B}

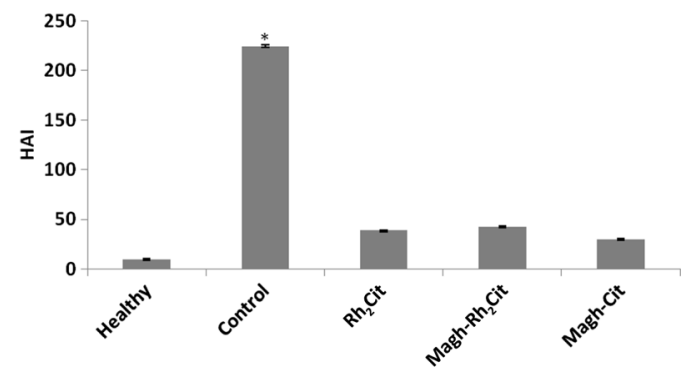

functions. b Histopathological alteration index (HAI) was divided into 0 $10=$ normal tissue, $11-20=$ mild to moderate damage to the tissue, $21-$ $50=$ moderate to severe damage to the tissue, $51-100=$ severe damage to the tissue, and greater than $100=$ irreparable damage to the tissue. Asterisk indicates significant differences $\left({ }^{*} p<0.05\right)$

causes include any cause that results in obstruction of the lower urinary system [46]. In the present study, the creatinine levels of all groups of mice bearing breast cancer was significantly lower compared to healthy mice (Table 1). Thus, we found no impairment of kidney function by the treatments, and the change in creatinine levels could be related to the development of the tumor since a decrease in creatinine levels has been reported as having no clinical significance [52]. Our histopathological analyses of the kidneys are supported by this conclusion, since no morphological alterations in the kidneys were found (Fig. 4b, e, h, k, n). These data are in agreement with our previous report with the same formulations when intratumorally administered [24].

\section{Conclusion}

In summary, we demonstrated by intravenous administration that Magh- $\mathrm{Rh}_{2} \mathrm{Cit}$ and Magh-Cit promoted a significant

Table 2 Quantitative parameters of hepatocyte measurements in healthy Balb/c mice and mice bearing 4T1 breast carcinoma without treatment or treated with $\mathrm{Rh}_{2} \mathrm{Cit}$, Magh- $\mathrm{Rh}_{2} \mathrm{Cit}$, and Magh-Cit

\begin{tabular}{|c|c|c|c|c|c|}
\hline Groups & Healthy & Control & $\mathrm{Rh}_{2} \mathrm{Cit}$ & Magh- $\mathrm{Rh}_{2} \mathrm{Cit}$ & Magh-Cit \\
\hline Hepatocyte area $\left(\mu \mathrm{m}^{2}\right)$ & $84.7 \pm 21.1$ & $85.7 \pm 7.8$ & $72.3 \pm 12.9$ & $83.5 \pm 10.4$ & $75.3 \pm 12.7$ \\
\hline Hepatocyte volume $\left(\mu \mathrm{m}^{3}\right)$ & $600.3 \pm 234.1$ & $599.2 \pm 85.8$ & $468.9 \pm 129.0$ & $577.5 \pm 116.5$ & $497.1 \pm 131.0$ \\
\hline Cytoplasm area $\left(\mu \mathrm{m}^{2}\right)$ & $75.6 \pm 20.3$ & $72.0 \pm 7.6$ & $62.5 \pm 11.9$ & $73.4 \pm 9.3$ & $66.1 \pm 12.0$ \\
\hline Cytoplasm volume $\left(\mu \mathrm{m}^{3}\right)$ & $508.2 \pm 201.4$ & $462.0 \pm 73.0$ & $376.9 \pm 105.0$ & $476.3 \pm 91.6$ & $409.9 \pm 109.5$ \\
\hline Cytoplasmic/nuclear ratio $\left(\mu \mathrm{m}^{2}\right)$ & $8.3 \pm 1.6$ & $5.2 \pm 1.7$ & $6.32 \pm 2$ & $7.2 \pm 1.8$ & $7.2 \pm 1.1$ \\
\hline Nucleus area $\left(\mu \mathrm{m}^{2}\right)$ & $9.0 \pm 1.6$ & $13.7 \pm 1.7 * a$ & $9.8 \pm 2.0^{*} \mathrm{~b}$ & $10.0 \pm 1.8 * \mathrm{~b}$ & $9.1 \pm 1.1 * b$ \\
\hline Diameter of nucleus $(\mu \mathrm{m})$ & $3.7 \pm 0.2$ & $4.1 \pm 0.4$ & $4.0 \pm 0.3$ & $4.0 \pm 0.3$ & $3.9 \pm 0.3$ \\
\hline Nucleus volume $\left(\mu \mathrm{m}^{3}\right)$ & $20.8 \pm 5.3$ & $38.3 \pm 7.3 * \mathrm{a}$ & $23.7 \pm 7.6 * b$ & $24.3 \pm 6.7 * b$ & $20.9 \pm 3.8 * b$ \\
\hline
\end{tabular}

Letters indicate significant differences in 2-by-2 comparisons detected by the Tukey test, with $a=$ significant compared to the healthy group and $b=$ significant compared to the control group. Results are expressed as mean $\pm \mathrm{SE}$ of the mean

$* p<0.05$ 
decrease in tumor area and did not induce toxicity effects in tested experimental conditions. No studies about the systemic action of rhodium (II) citrate-loaded maghemite nanoparticles have been carried out, making this report a suitable starting point for exploring the therapeutic potential of these compounds in treating breast cancer.

Acknowledgments We are grateful to Sabin Institute/Sabin Laboratories for technical support in the hematology and biochemical dosages, and the Brazilian National Council for Technological and Scientific Development $(\mathrm{CNPq})$, the Foundation to Support Research in the Federal District (FAPDF), the Coordination for Further Training of Graduate Staff (CAPES), the CAPES-Rede CON-NANO, NCT-Nanobiotecnologia, and CNANO-UnB for financial support.

Open Access This article is distributed under the terms of the Creative Commons Attribution License which permits any use, distribution, and reproduction in any medium, provided the original author(s) and the source are credited.

\section{References}

1. American Cancer Society's. What are the key statistics about breast cancer? 2013. http://www.cancer.org/cancer/breastcancer/ detailedguide/breast-cancer-key-statistics. Accessed 21 Dec 2013.

2. Dhankhar R, Vyas SP, Jain AK, Arora S, Rath G, Goyal AK. Advances in novel drug delivery strategies for breast cancer therapy. Artif Cells Blood Substit Immobil Biotechnol. 2010;38(5):230-49. doi:10.3109/10731199.2010.494578.

3. Verrill M. Chemotherapy for early-stage breast cancer: a brief history. Br J Cancer. 2009; 101(S1):S2-5.

4. World Health Organization (WHO). Breast Cancer Awareness Month in October. http://www.who.int/cancer/events/breast_cancer_month/ en/. Accessed 22 Apr 2013 (2013).

5. Instituto Nacional de Câncer (INCA). Tipos de câncer - Mama. Brazil. 2012. http://www.inca.gov.br/wps/wcm/connect/ tiposdecancer/site/home/mama. Accessed 12 Dec 2013 (2013).

6. Boyle P, Levin B. World cancer report 2008. Lyon: World Health Organization (WHO); 2008.

7. Lübbe A, Bergemann C, Huhnt W, Fricke T, Riess H, Brock J, et al. Preclinical experiences with magnetic drug targeting: tolerance and efficacy. Cancer Res. 1996;56(20):4694-701.

8. Fahmy TM, Fong PM, Goyal A, Saltzman WM. Targeted for drug delivery. Materials Today. 2005;8(8, Supplement):18-26. doi: 10. 1016/S1369-7021(05)71033-6.

9. Yih T, Al-Fandi M. Engineered nanoparticles as precise drug delivery systems. J Cell Biochem. 2006;97(6):1184-90.

10. Gref R, Minamitake Y, Peracchia M, Trubetskoy V, Torchilin V, Langer R. Biodegradable long-circulating polymeric nanospheres. Science. 1994;263(5153):1600-3. doi:10.1126/science.8128245.

11. Kim GJ, Nie S. Targeted cancer nanotherapy. Materials Today. 2005;8(8, Supplement):28-33. doi: 10.1016/S1369-7021(05)71034-8.

12. Berry CC, Curtis ASG. Functionalisation of magnetic nanoparticles for applications in biomedicine. J Phys D: Appl Phys. 2003;36: R198-206.

13. Sledge Jr GW, Miller KD. Exploiting the hallmarks of cancer: the future conquest of breast cancer. European Journal of Cancer. 2003;39(12):1668-75. doi: 10.1016/S0959-8049(03)00273-9.

14. Teicher BA. Molecular targets and cancer therapeutics: discovery, development and clinical validation. Drug Resistance Updates. 2000;3(2):67-73. doi: 10.1054/drup.2000.0123.
15. Tartaj P, Morales MP, Veintemillas-Verdaguer S, González-Carreño T, Serna CJ. The preparation of magnetic nanoparticles for applications in biomedicine. J Phys D: Appl Phys. 2003;36(13):R182.

16. Ren C. nanotechnology and the new age of cancer treatment. The National High School Journal of Science. 2012. http://nhsjs.com/ 2012/nanotechnology-and-the-new-age-of-cancer-treatment. Accessed 22 Apr 2013.

17. Hughes GA. Nanostructure-mediated drug delivery. Nanomedicine. 2005;1(1):22-30. doi: 10.1016/j.nano.2004.11.009.

18. Li F-R, Yan W-H, Guo Y-H, Qi H, Zhou H-X. Preparation of carboplatin-Fe@C-loaded chitosan nanoparticles and study on hyperthermia combined with pharmacotherapy for liver cancer. International Journal of Hyperthermia. 2009;25(5):383-91. doi:10. 1080/02656730902834949.

19. Kettering M, Zorn H, Bremer-Streck S, Oehring H, Zeisberger M, Bergemann $\mathrm{C}$, et al. Characterization of iron oxide nanoparticles adsorbed with cisplatin for biomedical applications. Phys Med Biol. 2009;54(17):5109-21.

20. Zyngier S, Kimura E, Najjar R. Antitumor effects of rhodium (II) citrate in mice bearing Ehrlich tumors. Braz J Med Biol Res. 1989;22(3):397-401.

21. Silva Nunes E, Carneiro M, Oliveira R, Báo S, Souza A. Colloidal stability, surface characterisation and intracellular accumulation of Rhodium(II) citrate coated superparamagnetic iron oxide nanoparticles in breast tumour: a promising platform for cancer therapy. Journal of Nanoparticle Research. 2013;15(6):1-15. doi:10.1007/ s11051-013-1683-5.

22. Weinberg R. The biology of cancer. 2nd ed. New York: Taylor \& Francis Group; 2013.

23. Carneiro M, Nunes E, Peixoto R, Oliveira R, Lourenco L, da Silva I, et al. Free rhodium (II) citrate and rhodium (II) citrate magnetic carriers as potential strategies for breast cancer therapy. Journal of Nanobiotechnology. 2011;9(1):11.

24. Carneiro MLB, Peixoto R, Joanitti G, Oliveira R, Telles L, MirandaVilela A, et al. Antitumor effect and toxicity of free rhodium (II) citrate and rhodium (II) citrate-loaded maghemite nanoparticles in mice bearing breast cancer. Journal of Nanobiotechnology. 2013;11(1):4

25. Gao Y, Gao Y, Guan W, Huang L, Xu X, Zhang C, et al. Antitumor effect of para-toluenesulfonamide against lung cancer xenograft in a mouse model. Journal of Thoracic Disease. 2013;5(4):472-83.

26. Hohenforst-Schmidt W, Zarogoulidis P, Darwiche K, Vogl T, Goldberg E, Huang $\mathrm{H}$, et al. Intratumoral chemotherapy for lung cancer: re-challenge current targeted therapies. Drug Des Devel Ther. 2013;7:571-83.

27. Sledge GW, Neuberg D, Bernardo P, Ingle JN, Martino S, Rowinsky EK, et al. Phase III trial of doxorubicin, paclitaxel, and the combination of doxorubicin and paclitaxel as front-line chemotherapy for metastatic breast cancer: an intergroup trial (E1193). Journal of Clinical Oncology. 2003;21(4):588-92. doi:10.1200/jco.2003.08. 013.

28. Pulaski BA, Ostrand-Rosenberg S. Mouse $4 \mathrm{~T} 1$ breast tumor model. Current protocols in immunology. New York: Wiley; 2001.

29. Garber K. Realistic rodents? Debate grows over new mouse models of cancer. J Natl Cancer Inst. 2006;98(17):1176-8.

30. Carneiro M, Joanitti G, Longo J, Peixoto R, Báo S. Microscopy features of mice cancer models induced by tumor cell transplantation and chemical agents. In: Mendez-Vilas A, Diaz J, editors. Microscopy: science, technology, applications and education. Badajoz: Formatex Research Center; 2010. p. 946-52.

31. Kang YS, Risbud S, Rabolt JF, Stroeve P. Synthesis and characterization of nanometer-size $\mathrm{Fe} 3 \mathrm{O} 4$ and $\gamma$-Fe2O3 particles. Chem Mater. 1996;8(9):2209-11. doi:10.1021/cm960157j.

32. American Veterinary Medical Association (AVMA). AVMA guidelines on euthanasia. 2007. https://www.avma.org/KB/Policies/ Documents/euthanasia.pdf. Accessed 11 Aug 2012. 
33. Kukowska-Latallo JF, Candido KA, Cao Z, Nigavekar SS, Majoros IJ, Thomas TP, et al. Nanoparticle targeting of anticancer drug improves therapeutic response in animal model of human epithelial cancer. Cancer Research. 2005;65(12):5317-24. doi:10.1158/00085472.can-04-3921.

34. Poleksić V, Mitrović-Tutundžić V. Fish gills as a monitor of sublethal and chronic effects of pollution. In: Müller R, Lloyd R, editors. Sublethal and chronic effects of pollutants on freshwater fish. Oxford: Fishing News Books; 1994. p. 339-52.

35. Vertemati M, Vizzotto L, Moscheni C, Dhillon A, Dhillon A, Quaglia A. A morphometric model to minimize subjectivity in the histological assessment of hepatocellular carcinoma and its precursors in cirrhosis. Microscopy Research and Technique. 2008;71(8):606-13. doi: 10.1002/jemt.20595.

36. Golalipour M, Ghafari S, Farsi M. Effect of Urtica dioica L extract on quantitative morphometric alterations of liver parenchymal cells in STZ diabetic rats. Sociedad Chilena de Anatomía. 2009;27(4). doi: 10.4067/S0717-95022009000400058.

37. Ke WM, Xie SB, Yu LN, Liu T, Lai J, He DQ, et al. Decline of serum HBV DNA and no change apportioned by the same hepatic parenchyma cell volume from hepatic fibrosis stage 1 to stage 4 during the natural history of chronic hepatitis B. Intervirology. 2008;51(4):235-40.

38. Sarfati G, Dvir T, Elkabets M, Apte RN, Cohen S. Targeting of polymeric nanoparticles to lung metastases by surface-attachment of YIGSR peptide from laminin. Biomaterials. 2011;32(1):152-61.

39. Kwok JC, Richardson DR. The iron metabolism of neoplastic cells: alterations that facilitate proliferation? Critical Reviews in Oncology/ Hematology. 2002;42(1):65-78. doi: 10.1016/S1040-8428(01) 00213-X.

40. Hraš AR, Hadolin M, Knez Ž, Bauman D. Comparison of antioxidative and synergistic effects of rosemary extract with $\alpha$-tocopherol, ascorbyl palmitate and citric acid in sunflower oil. Food Chem. 2000;71(2):229-33. doi: 10.1016/S0308-8146(00)00161-8.

41. Halabe BA. The biological significance of cancer: mitochondria as a cause of cancer and the inhibition of glycolysis with citrate as a cancer treatment. Med Hypotheses. 2007;69(4):826-8.

42. Halabe BA. Hypothesis proved...citric acid (citrate) does improve cancer: a case of a patient suffering from medullary thyroid cancer. Med Hypotheses. 2009;73(2):271.
43. Halabe BA. Clinical report: a patient with primary peritoneal mesothelioma that has improved after taking citric acid orally. Clin Res Hepatol Gastroenterol. 2011;35(3):241. doi:10.1016/j.clinre.2010. 12.011 .

44. Everds NE. Hematology of the laboratory mouse. In: Fox JG, Barthold SW, Davisson MT, Newcomer CE, Quimby FW, Smith AL, editors. The mouse in biomedical research: normative biology, husbandry, and models. San Diego: Elsevier; 2007. p. 133-70.

45. Thrall MA, Baker DC, Campbell TW, DeNicola D, Fettman MJ, Lassen ED, et al. Hematologia e Bioquímica Clínica Veterinária. 1st ed. São Paulo: Editora Roca; 2007.

46. Ramaiah S. A toxicologist guide to the diagnostic interpretation of hepatic biochemical parameters. Food Chem Toxicol. 2007;45(9): 1551-7.

47. Quimby FW, Luong RH. Clinical chemistry of the laboratory mouse. In: Fox JG, Barthold SW, Davisson MT, Newcomer CE, Quimby FW, Smith AL, editors. The mouse in biomedical research: normative biology, husbandry, and models. San Diego: Elsevier; 2007. p. 171216.

48. Sutherland RJ. Biochemical evaluation of the hepatobiliary system in dogs and cats. Vet Clin North Am Small Anim Pract. 1989;19(5): 899-927.

49. Singh A, Bhat T, Sharma O. Clinical biochemistry of hepatotoxicity. J Clinic Toxicol. 2011;S4(001):1-19. doi:10.4172/2161-0495.S4001.

50. Langiano VdC, Martinez CBR. Toxicity and effects of a glyphosatebased herbicide on the Neotropical fish Prochilodus lineatus. Comp Biochem Physiol C Toxicol Pharmacol. 2008;147(2):222-31. doi: 10.1016/j.cbpc.2007.09.009.

51. Miras-Parra FJ, Parra-Ruiz J, Gómez-Morales M, Gómez-Jiménez FJ, de la Higuera-Torres-Puchol J. Inflammatory pseudotumor of lymph nodes with focal infiltration in liver and spleen. Dig Dis Sci. 2003;48(10):2003-4.

52. Abdelhalim M, Jarrar B. Histological alterations in the liver of rats induced by different gold nanoparticle sizes, doses and exposure duration. J Nanobiotechnology. 2012;10(1):5.

53. Motta V. Enzimas. Porto Alegre: Editora Médica Missau; 2003. p. 232-46. 